at the Institute of Dental Surgery, London, and Mount Vernon Hospital, Middlesex, for the supervisor and instructor of Thailand's School of Dentistry, and an assistant surgeon of the Mandalay General Hospital is taking a three-year postgraduate course in dentistry at the Dental School, Guy's Hospital, while at the request of Thailand a one-year course in applied nutrition and food sciences was arranged at the London School of Hygiene. A health educator and public health inspector from Malaya is studying for a diploma in health education at the Institute of Education, London, and Pakistan has been assisted to start the F.R.C.S. (Primary) course of the Royal College of Surgeons, London, while to meet the shortage of qualified anæsthetists in Burma, a civil assistant surgeon is following a two-year course in anæsthesiology at the Postgraduate Medical School, London.

In education, Britain arranged a two-year course in concrete technology for an assistant professor of the College of Technology, Coinbatore; a librarian from Malaya is following a one-and-a-half year course in librarianship at the North-Western Polytechnic, London; five trainees from Malaya, Indonesia and the Philippines attended a course in tropical agriculture offered by the British Government, and an engineer from Nepal a postgraduate course in chemical engineering at Battersea College of Technology. Seven teachers from Indonesia's Science Teaching Centre, Bandung, are attending two- to threeyear courses in teaching science at Sheffield; science laboratory equipment, chemicals and books were supplied to five State high schools in the Shan States of Burma. A postgraduate course for two trainees from the University of Philippines was arranged at the Royal College of Science and Technology, Glasgow, and arrangements made for the senior lecturer of the Physics Department, University of Sind, to undertake nuclear research at Trinity College, Oxford, while a trainee from the Birbal Sahni Institute of Palæobotany is taking a postgraduate course at Queen's University of Belfast. The President of Burma's Shan State Civil Service is being trained in public administration in Britain, while five Laotian trainees attended a six-month course at the Royal Institute of Public Administration.

\title{
THE UPPER CRETACEOUS OF CENTRAL EUROPE
}

$\mathrm{T}$ HE Palæontological Section of the Geological Society in the German Democratic Republic held a sym. posium in Dresden during October 2-7, 1962, on "Problems of the Stratigraphy and Palæontology of the Cenomanian to Coniacian Stages in Central Europe". Three days of papers with discussion and three days of excursions in Saxony were organized by Dr. H. Prescher of the Staatliches Museum für Mineralogie und Geologie zu Dresden and Dr. K.-A. Tröger of the Geologisches Institut der Bergakademie Freiberg (Sachs). The meetings were attended by some thirty geologists, mostly from the German Democratic Republic, but also from Czechoslovakia, Hungary, Poland and Great Britain. The eighteen papers read will be published early in 1963 in the Berichte der Geologischen Gesellschaft in der D.D.R.

General reviews of the present state of knowledge of the Upper Cretaceous in Bohemia were given by $F$. Macák and V. Müller and in papers sent in by J. Soukup and J. Dvorák. A useful summary has already been published by Soukup in tabular form with German transliterations of all the Czech localities mentioned.

The extensive work by Polish geologists on the flyschfacies of the Carpathians, thrust northwards into southern Poland, has become well known in Britain in recent years, mainly through the work of M. Ksiazkiewicz and his colleagues at Krakow ${ }^{2,3}$. The post-war work on the boreal facies in Poland is, as yet, less well known. A general summary of this recent work was given by $\mathbf{S}$. Cieśliński, who has already published work on the Albian and Cenomanian which has faunal and facies similarities to north-west Europe ${ }^{4,5}$. For the symposium he had prepared a map which showed the Cretaceous basins in Poland and the facies-succession distribution in each basin. The Silesian-north Sudetic Cretaceous, lying to the southwest of the Sudetenrand Fracture, Eule Gneiss and the North Sudetic Schiefergebirge, was discussed in more detail by $J$. Milewicz, and is distinct from the rest of Poland, being allied to the Saxony-Bohemian region.

Six of the papers were largely or entirely concerned with Saxony itself. Much detailed work has been done here since the comprehensive summary by Seifert ${ }^{6}$. The fresh-water beds, widely developed at the base, have already been studied by Prescher ${ }^{7}$ and Barthel ${ }^{8}$. W. Krutzsch (president of the Palæontology Section) gave an account of the micro-flora obtained from a boring at Königstein. Of the marine formations, not only the Unterquader but also the Plenus Zone has commonly been included in the Cenomanian by Saxon geologists; the Czechs have considered the Plenus Zone to be Turonian and this conforms with British usage; some Czech and Saxon geologists now refer to it as a transitional zone between the two stages. In Saxony the Plenus Zone contains Metoicoceras spp., which show that it corresponds to the Actinocamax Plenus Zone in England.

Detailed isopachytes for the Unterquader plus Plenus Zone prepared by F. Decker show that Seifert's palæogeographical maps are misleading and must have depended much on guesswork, at least for land-sea distribution. Decker's map shows a general increase of thickness to the north-east of the Elbtalgebiet beneath the southwesterly overthrust Lausitzer granodiorite. The same granodiorite conceals sediments of the North Sudetic Basin as shown by borings near Spremberg reported on by W. Haller. One of these showed some $1,100 \mathrm{~m}$ of marly clays and fine sandstones embracing only the Turonian to Lower Campanian. The coring was sufficiently wide to allow recovery of a considerable fauna of ammonites and Inoceramus spp.

The considerable thicknesses of detrital shelf sediments in Saxony above the Cenomanian were noticeable in the excursions. In southern Saxony there are more than $500 \mathrm{~m}$ of orthoquartzites (the Quadersandstein) in the Turonian alone. The provenance of this sand is still a problem and H.-D. Beeger has found that the non-opaque heavy minerals are almost confined to the stable trio zircon, tourmaline and rutile. Current bedding is often not developed and does not give a consistent pattern. The contrast with north-west Europe is further shown by the scarcity of glauconite and rarity of phosphate.

The next session of the Geological Society in the German Democratic Republic will be in Leipzig during May 13-18, 1963, on the theme "Facies". Further information can be obtained from J. Lamprecht, Wiss. Sekretär der Geologischen Gesellschaft in der D.D.R., Berlin N4, Invalidenstrasse 44, German Democratic Republic.

J. M. HaNCOCK

${ }^{1}$ Soukup, J., Jb. Staatl. Mus. Mineral. Geol. Dresden, 5, 85 (1960).

${ }^{2}$ Ksiazkiewicz, M., Sond. Geolog. Runds., 45, No. 2, 369 (1956).

${ }^{3}$ Ksiazkiewicz, M., Proc. Geol. Soc. Lond., No. 1587, 70 (1961).

${ }^{4}$ Cieśliński, S., Inst. Geol. Warszawa., 28 (1959).

${ }^{3}$ Cieśliński, S., Inst. Geol. Warszawa., 30 (1960).

- Seifert, A., Freiberg. Forschungs., C 14 (1955).

7 Prescher, H., Freiberg. Forschungs., C 34 (1957).

${ }^{8}$ Barthel, M., Jb. Staatl. Mus. Mineral. Geol. Dresden, 4, 102 (1958). 